\title{
New records of rhodolith-forming species (Corallinales, Rhodophyta) from deep water in Espírito Santo State, Brazil
}

\author{
Maria Carolina Henriques • Alexandre Villas-Boas • \\ Rafael Riosmena Rodriguez $\cdot$ Marcia A. O. Figueiredo
}

Received: 20 August 2010/Revised: 30 May 2011/Accepted: 5 July 2011/Published online: 17 July 2011

(C) Springer-Verlag and AWI 2011

\begin{abstract}
Little is known about the diversity of nongeniculate coralline red algae (Rhodophyta, Corallinophycidae) from deep waters in Brazil. Most surveys undertaken in this country have been carried out in shallow waters. In 1994, however, the REVIZEE program surveyed the sustainable living resources potential of the Brazilian exclusive economic zone to depths of $500 \mathrm{~m}$. In the present study, the rhodolith-forming coralline algae from the continental shelf of Espírito Santo State were identified. Samples were taken from 54 to $60 \mathrm{~m}$ depth by dredging during ship cruises in 1997. Three rhodolith-forming species were found: Spongites yendoi (Foslie) Chamberlain, Lithothamnion muelleri Lenormand ex Rosanoff and Lithothamnion glaciale Kjellman. These records extend the distribution ranges of these species into Brazilian waters and extend the depth distribution of non-geniculate coralline red algae into Brazilian water to $58 \mathrm{~m}$.
\end{abstract}

Keywords Corallinales · Taxonomy $\cdot$ Spongites . Lithothamnion · Brazil

Communicated by H.-D. Franke.

M. C. Henriques $(\square)$

Museu Nacional/Universidade Federal do Rio de Janeiro, Av General Herculano Gomes s/n, Quinta da Boa Vista, São Cristovão, Rio de Janeiro, RJ, Brazil

e-mail: mhenriques@jbrj.gov.br

A. Villas-Boas · M. A. O. Figueiredo

Instituto de Pesquisas Jardim Botânico do Rio de Janeiro,

Rua Pacheco Leão 915, Rio de Janeiro, RJ 22460-030, Brazil

R. R. Rodriguez

Programa de Investigación en Botánica Marina, Departamento de Biología Marina, Universidad Autónoma de Baja California Sur, Apartado postal 19-B, 23080 La Paz, BCS, Mexico

\section{Introduction}

"Rhodolith" is the name given to free-living structures composed mostly ( $>50 \%$ ) of non-geniculate coralline red algae (Rhodophyta, Corallinophycidae). The communities they denominate are called "rhodolith beds" (Foster 2001; Harvey and Woelkerling 2007). However, there is no consensus on use of the terms (Foster 2001). In this study, we follow Foster (2001) and Harvey and Woelkerling (2007).

The deepest known alga is a rhodolith-forming coralline red algal species discovered on an uncharted seamount at $268 \mathrm{~m}$ depth in the Bahamas (Littler et al. 1985). Little is known about the diversity of non-geniculate coralline red algae from Brazil deep water (Amado-Filho et al. 2007; Villas-Boas et al. 2009) in general and of rhodolith-forming species in particular. The Brazilian continental shelf contains extensive rhodolith beds from 20 to $100 \mathrm{~m}$ depth (Kempf et al. 1969; Kempf 1980; Amado-Filho et al. 2007) distributed from $3^{\circ}$ to $22^{\circ} \mathrm{S}$ and is considered the largest area supporting rhodolith beds in the world (Foster 2001).

The continental shelf of Espírito Santo State is considered to be the region with highest marine algal species richness in Brazil (Amado-Filho et al. 2007) and is a transitional area from tropical to temperate floras (Guimarães 2003). Despite the urgent need to understand and preserve the marine biodiversity within rhodolith beds, which are a critical habitat for conservation, shallow rhodolith beds from Espirito Santo State have only recently been studied (Amado-Filho et al. 2007, 2010; Villas-Boas et al. 2009). Five rhodolith-forming genera (Lithothamnion, Lithophyllum, Hydrolithon, Neogoniolithon and Sporolithon) were reported from the region (Amado-Filho et al. 2007). VillasBoas et al. (2009) report three rhodolith-forming species from the genus Lithophyllum [L. corallinae (Crouan and 
Crouan) Heydrich, L. johansenii Woelkerling and Campbell, L. stictaeforme (Areschoung in J. Agardh) Hauck], already known to science, and one rhodolith-forming species (L. depressum Villas-Boas, Figueiredo et RiosmenaRodriguez) new to science. Besides these, two other species were reported from the region (Lithothamnion muelleri Lenormand ex Rosanoff and Mesophyllum engelhartii (Foslie) Adey) (Amado-Filho et al. 2010).

A major survey evaluating the sustainable potential of living resources of the Brazilian Exclusive Economic Zone (REVIZEE program) was carried out in 1997. Its aim was to address potential fisheries resources and to identify the main benthic taxonomic groups on the outer shelf and continental slope from 50 to $500 \mathrm{~m}$ depth. Today, the REVIZEE program is the most widespread marine project carried out on the Brazilian coast generating biological, geological, physical and chemical data (Lavrado 2006). Rhodolith beds were recorded during fieldwork, but coralline algal species composition was not investigated. The material has been stored for later study (YoneshigueValentin et al. 2006). Thus, Brazilian deep-water marine ecosystems still remain poorly described.

The current study aims to contribute to the knowledge of coralline red algae in Espírito Santo state, Brazil. The study reports previously unrecorded rhodolith-forming species in Brazilian deep water, discussing the implications of these new records for rhodolith diversity in Brazil.

\section{Materials and methods}

Field work

Rhodolith samples were collected during field trips conducted from October to November of 1997 by the REVIZEE program (Lavrado 2006). The material was collected offshore along the Espírito Santo State continental shelf at three studies sites: $34 \mathrm{R}\left(20^{\circ} 45^{\prime} 00^{\prime \prime} \mathrm{S}-40^{\circ} 10^{\prime} 00^{\prime \prime} \mathrm{W}\right)$; 28R $\left(19^{\circ} 49^{\prime} 00^{\prime \prime} \mathrm{S}-37^{\circ} 56^{\prime} 00^{\prime \prime} \mathrm{W}\right)$; and $29 \mathrm{R}\left(19^{\circ} 48^{\prime} 01^{\prime \prime} \mathrm{S}-\right.$ $37^{\circ} 46^{\prime} 22^{\prime \prime} \mathrm{W}$ ). Depths ranged from 55 to $58 \mathrm{~m}$ depth (see Yoneshigue-Valentin et al. 2006 for site descriptions). The region is influenced by the Brazilian current that runs along the South Atlantic Ocean and is characterized by sea surface temperatures ranging from 21 to $27^{\circ} \mathrm{C}$ (Lavrado 2006). At $50 \mathrm{~m}$ depth, the region is influenced by the South Atlantic Central Waters (SACW) and is characterized by temperatures from 6 to $20^{\circ} \mathrm{C}$ (Silveira et al. 2000).

\section{Laboratory work}

Since 1997, the samples had been preserved in $4 \%$ formalin seawater (Yoneshigue-Valentin et al. 2006). As a consequence of this long preservation time, specimens were degraded, and it was difficult finding intact reproductive structures. The material was exhaustively sectioned, but in one case (Fig. 1d), we could not find a representative reproductive structure. Histological techniques for optical microscopy follow Moura et al. (1997). Microslides were prepared, and identification of material to species level followed descriptions of Chamberlain (1993), Chamberlain and Irvine (1994), and Wilks and Woelkerling (1995). Type specimens were not examined. Identified samples were incorporated in the herbarium collection of the Botanical Garden of Rio de Janeiro (RB). The herbarium code follows the Index Herbariorum (Holmgren and Holmgren 2011, continuously updated). Conceptacle measurements follow Adey and Adey (1973), thallus anatomical terminology follows Woelkerling (1988), growth form terminology follows Woelkerling et al. (1993) and typification data follow Woelkerling (1993).

\section{Results}

Taxonomic accounts

Three species were identified: Spongites yendoi (Foslie) Chamberlain (Fig. 1); Lithothamnion muelleri Lenormand ex Rosanoff (Figs. 2, 3); and Lithothamnion glaciale Kjellman (Figs. 4, 5).

Spongites yendoi (Foslie) Chamberlain, 1993: 102 (Fig. 1)

Basionym: Goniolothon yendoi Foslie, 1900a: 25

Further references: Penrose (1996)

Synonyms: See Chamberlain (1993)

Lectotype: TRH (Yendo no. 66) Foslie (1904)

Type locality: Shimoda Harbour, Izul, Japan, K. Yendo, April 1899

Description: Plants non-geniculate, thallus-forming freeliving rhodoliths with warty growth form (Fig. 1a) consisting of several layers of plants overgrowing one another. Spongites yendoi compose the most external layer. Cylindrical protuberances measuring $1-2 \mathrm{~mm}$ in height and $1 \mathrm{~mm}$ in diameter. Thallus pseudoparenchymatous with dorsiventral internal organization in encrusting portions and radial internal organization in protuberances. Monomerous thallus construction in encrusting portions (Fig. 1b) consisting of a single system of branched filaments that form a core running more or less parallel to the substratum and a more peripheral region in which portions of core filaments or their derivatives curve outwards toward the thallus surface terminating in one layer of flattened epithallial cells (Fig. 1c). The core region is plumose 

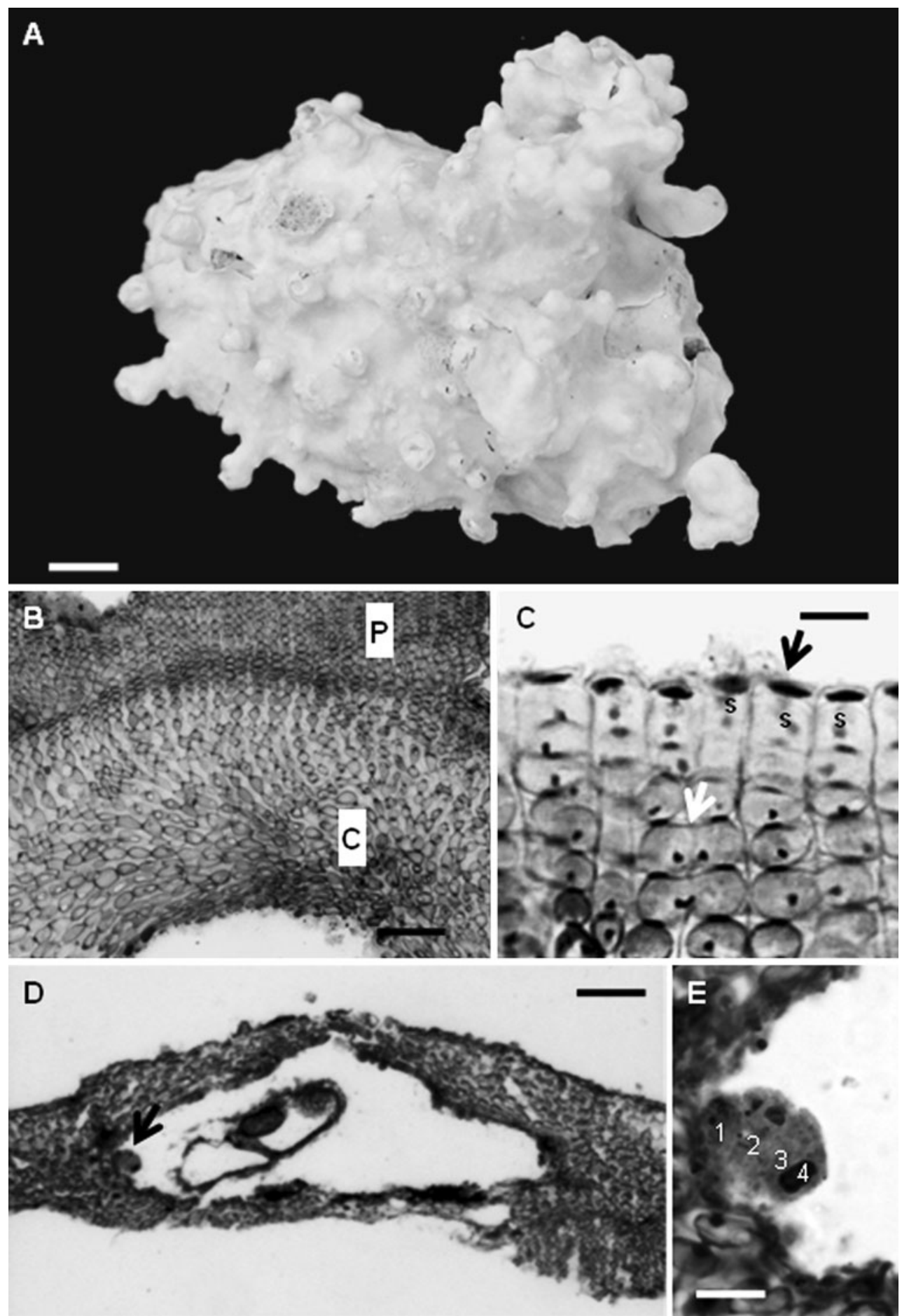

Fig. 1 Spongites yendoi. a Morphology of a rhodolith with warty growth form. Scale bar $2.5 \mathrm{~mm}$. (RB 458711). b Longitudinal section showing the internal monomerous thallus construction. $P$ peripheral region and $C$ core region. Scale bar $52 \mu \mathrm{m}$. (RB 458711). c Longitudinal section of the outer perithallium showing the flattened, but rounded epithallial cells (black arrow) and cell fusions between cells of adjacent peripheral filaments (white arrow), $\mathrm{S}=$ subepithallial initials cells. Scale bar $10.5 \mu \mathrm{m}$. (RB 458711). d Longitudinal section through a uniporate tetrasporangial conceptacle with roof protruding above the surrounding thallus surface. Note the tetrasporangium (arrow). Scale bar $45.7 \mu \mathrm{m}$. (RB 458711). e Longitudinal section showing a tetrasporangium in detail. Numbers 1-4 indicate the four spores in tetrasporangium. Scale bar $9 \mu \mathrm{m}$. (RB 458711) 

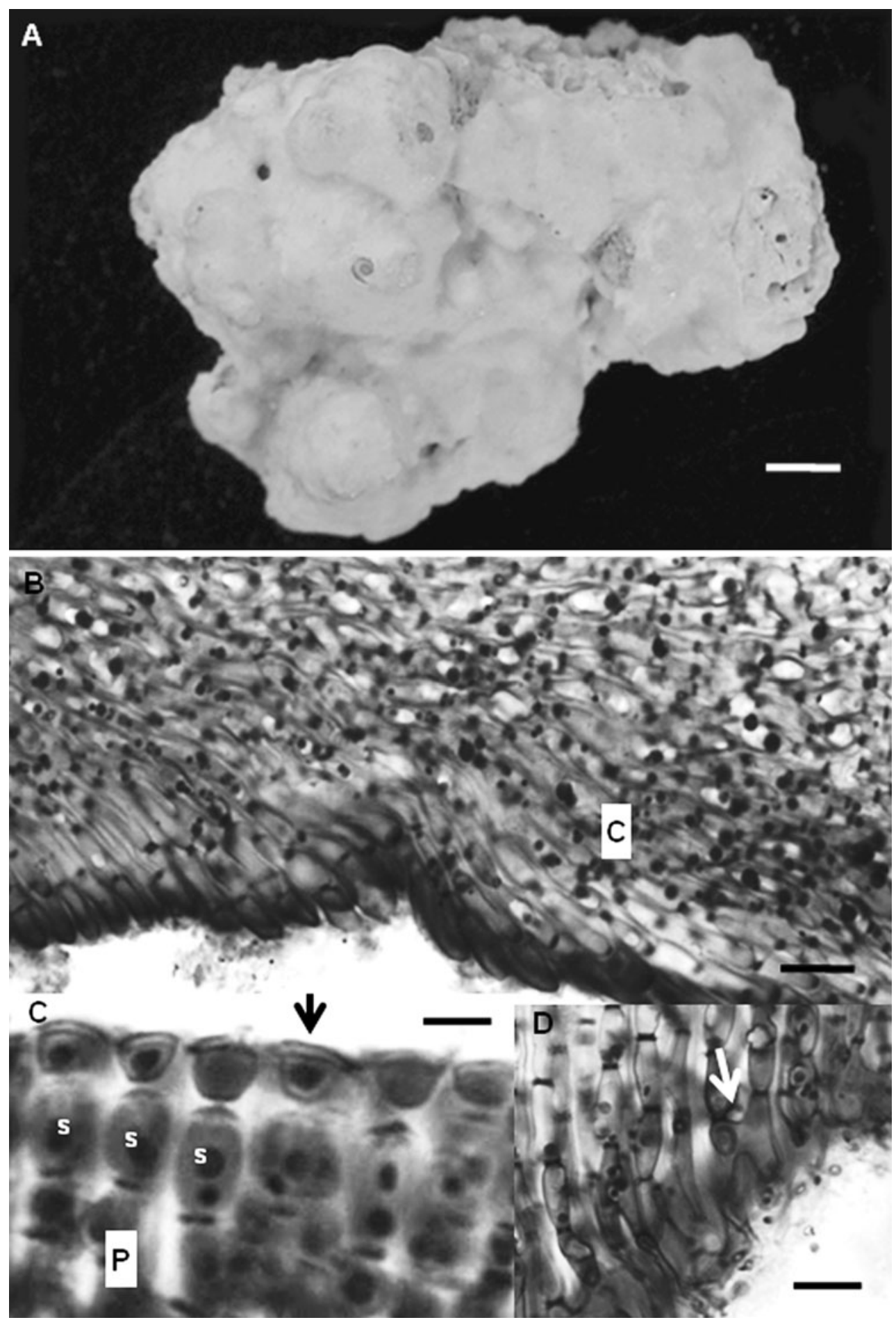

Fig. 2 Lithothamnion muelleri. a Morphology of a rhodolith with a warty growth form. Scale bar $4.5 \mathrm{~mm}$ (RB458708). b Longitudinal section showing the internal monomerous thallus construction. $C$ core region, Scale bar $16 \mu \mathrm{m}$ (RB458708). c Longitudinal section of the outer perithallium showing flared epithallial cells (arrow).

(non-coaxial), comprises most of the thallus thickness and is composed mainly of rectangular cells measuring 10-19 $\mu \mathrm{m}$ in length and 3-7 $\mu \mathrm{m}$ in diameter. Cells of the peripheral
$P$ peripheral region, $S$ subepithallial initials cells, scale bar $5 \mu \mathrm{m}$ (RB458708). d Longitudinal section showing perithallial filaments with cell fusions between cells of adjacent filaments (arrow). Scale bar $10 \mu \mathrm{m}$ (RB458708)

region are squarish and measure $4-8 \mu \mathrm{m}$ in length and 6-10 $\mu \mathrm{m}$ in diameter. Epithallial cells measure $2-3 \mu \mathrm{m}$ in length and 6-8 $\mu \mathrm{m}$ in diameter, and subepithallial initials 


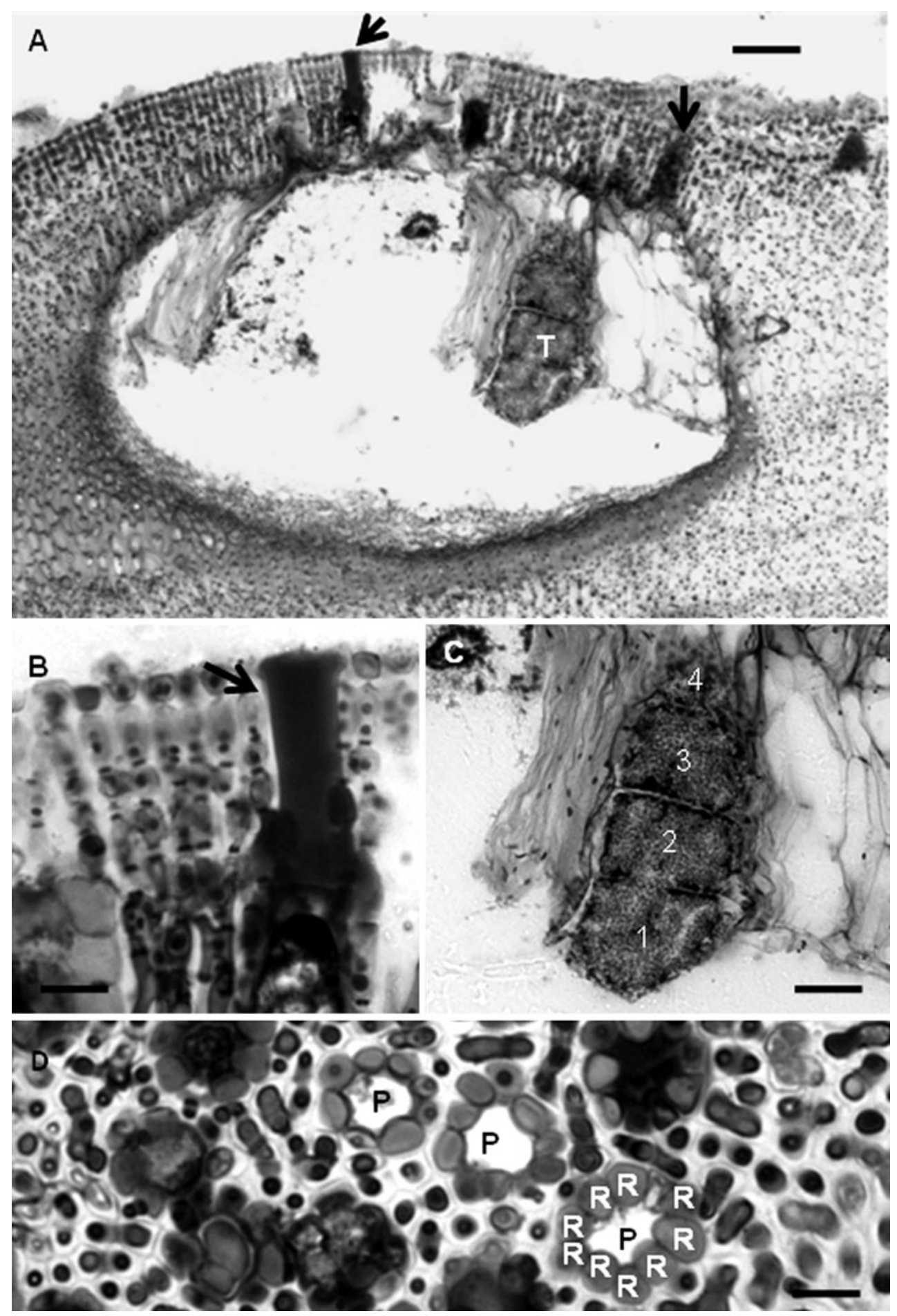

Fig. 3 Longitudinal section of Lithothamnion muelleri. a Multiporate tetrasporangial conceptacle. Note staining pore plugs (arrows), $T$ Tetraspore. Scale bar $50 \mu \mathrm{m}$ (RB458708). b Multiporate tetrasporangial conceptacle roof showing a densely staining pore plug (arrow). Scale bar $11 \mu \mathrm{m}$ (RB458708). c Tetrasporangium in detail.

cells measure $3-5 \mu \mathrm{m}$ in length and 6-8 $\mu \mathrm{m}$ in diameter (Fig. 1c). Cells of adjacent filaments are linked by lateral cell fusions (Fig. 1c); trichocytes have not been observed.
Numbers 1-4 indicate the four spores in tetrasporangium. Scale bar $28 \mu \mathrm{m}$ (RB458708). d Surface view of the pore plate of a tetrasporangial conceptacle showing pores $(\mathrm{P})$ surrounded by rosette cells (R). Scale bar $9.5 \mu \mathrm{m}$ (RB458708)

Tetrasporangial conceptacles uniporate with the roof more or less raised above the surrounding thallus surface (Fig. 1d). Conceptacle roofs 3-8 cells thick including the 

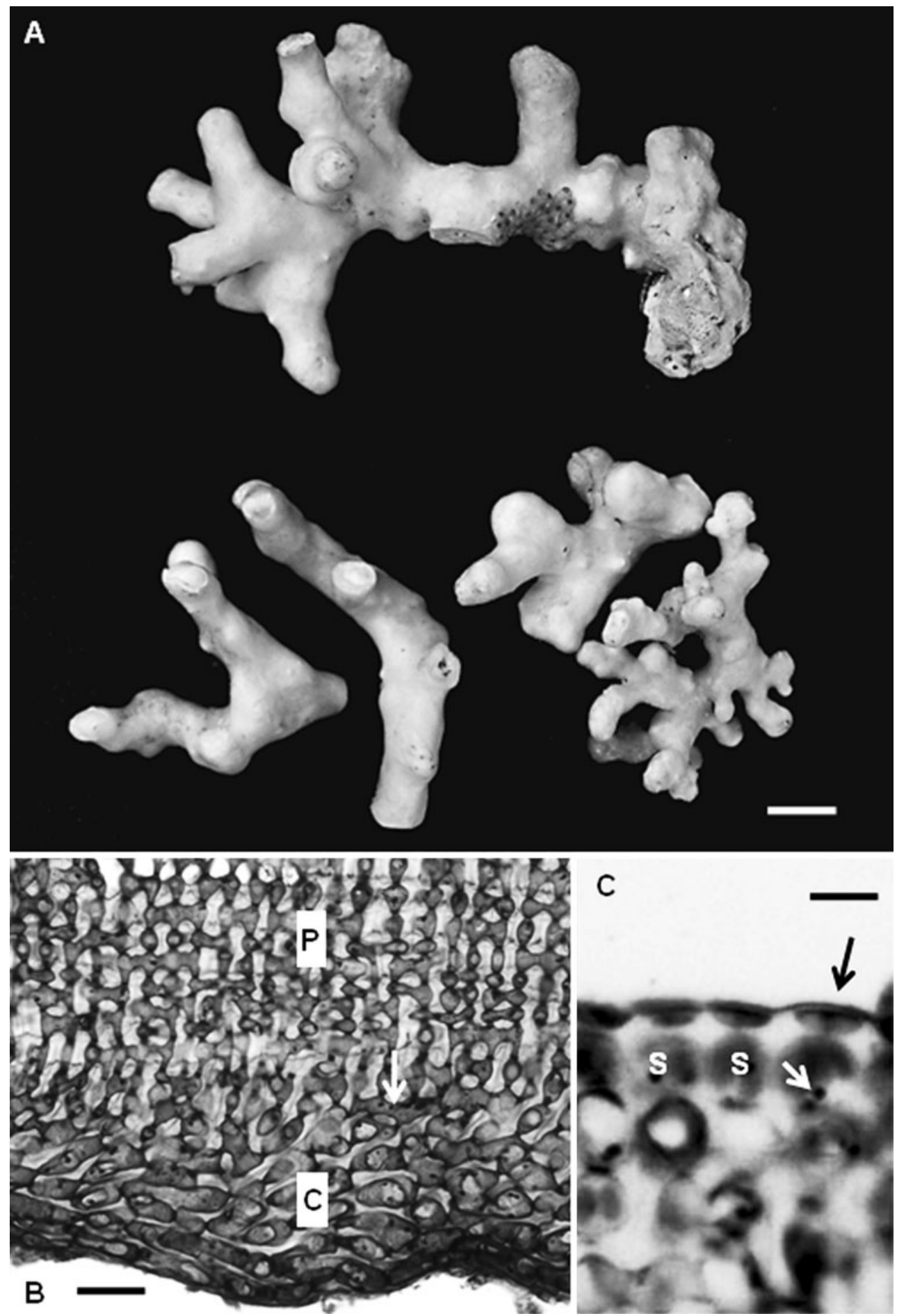

Fig. 4 Lithothamnion glaciale. a Morphology of a rhodolith with terete fructicose growth form. Scale bar $5.5 \mathrm{~mm}$ (RB 458706). b Longitudinal section showing the monomerous internal thallus construction and cell fusions. $P$ peripheral region and $C$ core region.

epithallial cells, pore without an apical plug. Conceptacle chambers 280-290 $\mu \mathrm{m}$ in diameter and 105-110 $\mu \mathrm{m}$ in height, usually without a central columella and with
Scale bar $23 \mu \mathrm{m}$ (RB 458706). c Longitudinal section of the outer perithallium showing flared epithallial cells (black arrow) and small bodies near the primary pit connections (white arrow), $S$ subepithallial initials cells. Scale bar $8.5 \mu \mathrm{m}$ (RB 458706)

chamber floors, located 13-15 cell layers below the thallus surface. Tetrasporangia (Fig. 1e) measure 13-15 $\mu \mathrm{m}$ in diameter and 17-20 $\mu \mathrm{m}$ in length. 

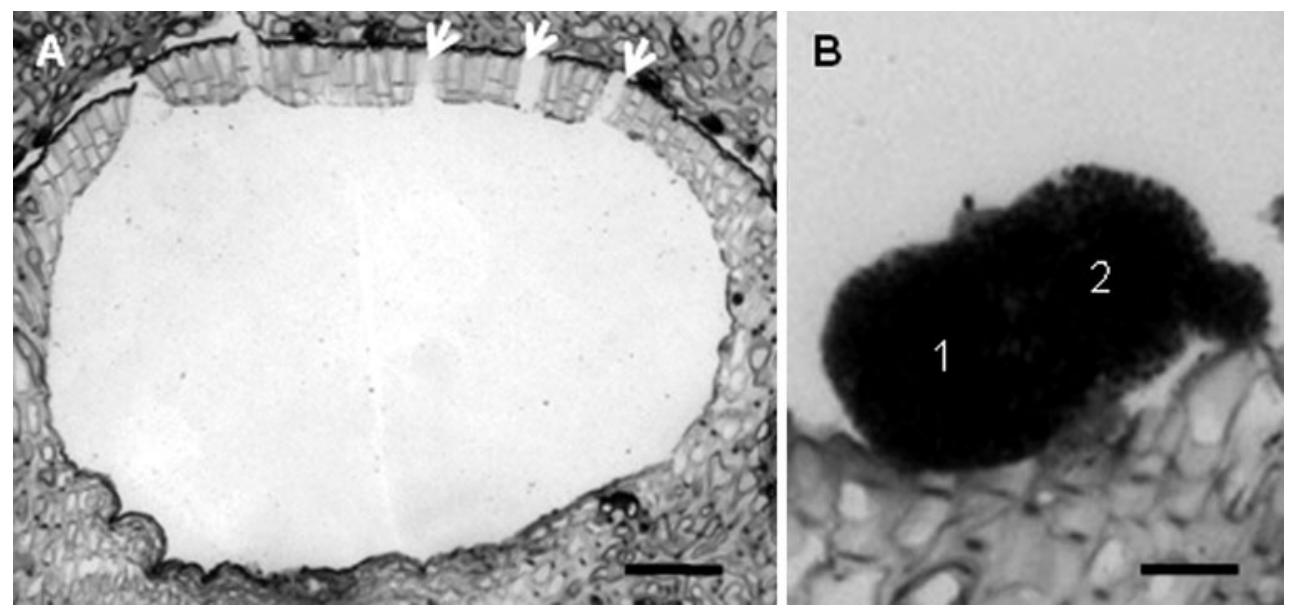

Fig. 5 Longitudinal section of Lithothamnion glaciale. a Bisporangial multiporate conceptacle. Note the pore plate (arrows). Scale bar $57 \mu \mathrm{m}$ (RB 458706). b Bisporangium in detail. Numbers 1 and 2 indicate the two spores in bisporangium. Scale bar $12 \mu \mathrm{m}$ (RB 458706)

Material examined: Ibiraçu, Espírito Santo, Brazil, $19^{\circ} 49^{\prime} 00^{\prime \prime} \mathrm{S}, 37^{\circ} 56^{\prime} 00^{\prime \prime} \mathrm{W}$ (54 m depth, 31.x.1997, RB 458711); Alegre, Espírito Santo, Brazil, $20^{\circ} 45^{\prime} 00^{\prime \prime} \mathrm{S}$, $40^{\circ} 10^{\prime} 00^{\prime \prime} \mathrm{W}$ (55 m depth, 03.xi.1997, RB 458712).

Comments: Most characters (Table 1) observed in the examined specimens agree with descriptions of $S$. yendoi from southern Australia (Penrose 1996) and South Africa (Chamberlain 1993). Spongites yendoi is a cosmopolitan species, occurring in tropical, temperate and polar regions (Chamberlain 1993; Penrose 1996). It has been reported for shallow areas of southern Namibia, South Africa, southern Mozambique (Chamberlain 1993; Maneveldt et al. 2008), Indonesia, Japan (Chamberlain 1993), eastern Australia (Lund et al. 2000), southern Australia (Penrose 1996), New Zealand (Harvey et al. 2005; Farr et al. 2009), Mexican tropical Pacific (Fragoso and Rodríguez 2002), Mexican tropical Atlantic and the Caribbean (Mateo-Cid et al. 2007). The current record extends both the species geographic distribution along the southwestern Atlantic and its vertical distribution down to $55 \mathrm{~m}$ depth.

Lithothamnion muelleri Lenormand ex Rosanoff, 1866: 101, pl. 6 figs 8-11 (Figs. 2, 3)

Further references: Wilks and Woelkerling (1995); Woelkerling (1996)

Synonyms: See Wilks and Woelkerling (1995)

Lectotype: $\mathrm{CN}$ (herb. Lenormand); from Western Port Bay, Victoria; collected by W. H. Harvey, 1851, communicated by F. Mueller; lectotype designated by Woelkerling (1983: 193) and Wilks and Woelkerling (1995, fig. 1A).

Isolectotypes: MEL 588439; L 941.149-249 (communicated by Lenormand)
Description: Plants non-geniculate, thallus-forming freeliving rhodoliths with warty growth form (Fig. 2a). Protuberances cylindrical, 1-3 $\mathrm{mm}$ in length and $1-3 \mathrm{~mm}$ in diameter. Thallus pseudoparenchymatous with dorsiventral internal organization. Monomerous thallus construction (Fig. 2b) consisting of a single system of branched filaments that forms a core running more or less parallel to the substratum and a more peripheral region in which portions of core filaments or their derivatives curve outwards toward the thallus surface. The developing filamentous core is plumose (non-coaxial) with cells of adjacent filaments not arranged in arching tiers. Cells of core filaments are rectangular measuring 7-18 $\mu \mathrm{m}$ in length and 3-9 $\mu \mathrm{m}$ in diameter. 16-22 layers of peripheral filaments in which cells are also rectangular measuring 12-17 $\mu \mathrm{m}$ in length and 5-7 $\mu \mathrm{m}$ in diameter and terminate in a single layer of flared epithallial cells (Fig. 2c) that measure 4-6 $\mu \mathrm{m}$ in length and 5-7 $\mu \mathrm{m}$ in diameter. Subepithallial initials cells measure $7-11 \mu \mathrm{m}$ in length and 4-7 $\mu \mathrm{m}$. Bead-like groups of fused cells (Fig. 2d). Core fusions are localized; trichocytes have not been observed.

Tetrasporangial conceptacles multiporate with roofs slightly raised above the surrounding thallus surface, 7-9 cells thick including the epithallial cell (Fig. 3a); apical pore channels with plugs (Fig. 3b). Conceptacle chambers 375-755 $\mu \mathrm{m}$ in diameter and 200-320 $\mu \mathrm{m}$ in height, usually without a central columella; tetrasporangia scattered across the chamber floor. Mature tetrasporangia long, measuring 145-147 $\mu \mathrm{m}$ in length and 57-59 $\mu \mathrm{m}$ in diameter, containing four zonately arranged tetraspores (Fig. 3c). Pore channels surrounded by $8-10$ rosette cells in surface view (Fig. 3d).

Material examined: Itaguaçu, Espírito Santo, Brazil, $19^{\circ} 48^{\prime} 01^{\prime \prime} \mathrm{S}, 37^{\circ} 46^{\prime} 22^{\prime \prime} \mathrm{W}$ (58 m depth, 16.xi.1997, RB 
Table 1 Comparison of characters of Spongites yendoi from Espiríto Santo state (Brazil) and other regions of the world

\begin{tabular}{|c|c|c|c|c|}
\hline & $\mathrm{Brazil}^{\mathrm{a}}$ & Mexico/Caribbean ${ }^{\mathrm{b}}$ & South Africa ${ }^{\mathrm{c}, \mathrm{d}}$ & Australia $^{\mathrm{e}}$ \\
\hline Growth form & Encrusting to warty & Encrusting & Encrusting to warty & Encrusting to lumpy \\
\hline Thallus construction & Monomerous & Monomerous & Monomerous & Monomerous/dímerous \\
\hline Arrangement of trichocytes & Not present & Mostly solitary & Solitary & ND \\
\hline $\begin{array}{l}\text { Cell number in tetrasporangial conceptacle } \\
\text { chamber roof }\end{array}$ & $3-8$ & ND & $4-7^{\mathrm{f}}$ & $3-5$ \\
\hline Tetrasporangial conceptacle chamber height & $105-110 \mu \mathrm{m}$ & $80-150 \mu \mathrm{m}$ & $\begin{array}{l}62-117 \mu \mathrm{m}^{\mathrm{a}} \\
109-185 \mu \mathrm{m}^{\mathrm{b}}\end{array}$ & $109-185 \mu \mathrm{m}$ \\
\hline Tetrasporangial conceptacle chamber diameter & $280-290 \mu \mathrm{m}$ & $180-295 \mu \mathrm{m}$ & $\begin{array}{l}147-207 \mu \mathrm{m}^{\mathrm{a}} \\
164-232 \mu \mathrm{m}^{\mathrm{b}}\end{array}$ & $164-232 \mu \mathrm{m}$ \\
\hline
\end{tabular}

$N D$ no data

a Present study

b Mateo-Cid et al. (2007)

c Chamberlain (1993)

d Penrose (1991)

e Penrose (1996)

f data taken from Chamberlain (1993), figure 6

458708); Ibiraçu, Espírito Santo, Brazil, $19^{\circ} 49^{\prime} 00^{\prime \prime} \mathrm{S}$, $37^{\circ} 56^{\prime} 00^{\prime \prime} \mathrm{W}$ (54 m depth, 31.x.1997, RB 458709); Alegre, Espírito Santo, Brazil $20^{\circ} 45^{\prime} 00^{\prime \prime} \mathrm{S}, 40^{\circ} 10^{\prime} 00^{\prime \prime} \mathrm{W}(55 \mathrm{~m}$ depth, 03.xi.1997, RB 458710).

Comments: Most characters (Table 2) observed in the examined specimens agree with descriptions of the same species from southern Australia (Wilks and Woelkerling 1995; Woelkerling 1996). According to Wilks and Woelkerling (1995), Lithothamnion muelleri occurs from Albany, (Western Australia) eastwards to Corner Inlet (Victoria) and in Bruny Island (Tasmania, southern Australia). The records from Tierra del Fuego require confirmation based on modern collections (Wilks and Woelkerling 1995). According to Yabur-Pacheco and Riosmena-Rodriguez (2006), there are also records in the southwestern Gulf of California, Mexico and other areas of the eastern Pacific (Riosmena-Rodríguez, unpublished data), but there is no description for the species for these areas yet. There are also records of this species in Chile (Ramírez and Santelices 1991) and in the French Antarctic, near South America (Joubin 1913). In Australia, it is abundant in shallow (Wilks and Woelkerling 1995; Woelkerling 1996) and deep waters down to $85 \mathrm{~m}$ (Woelkerling 1996). In the Gulf of California, it was found between 2 and $20 \mathrm{~m}$ with greater abundance in shallow waters (Yabur-Pacheco and Riosmena-Rodriguez 2006). The present record extends the species vertical distribution in Brazilian waters down to $58 \mathrm{~m}$ depth and confirms its affinity with cold waters.

Lithothamnion glaciale Kjellman, 1883: 123 pl. 2, 3. (Figs. 4, 5).
Further references: Adey (1970a); Adey and Adey (1973); Chamberlain and Irvine (1994)

Synonyms: See Chamberlain and Irvine (1994)

Lectotype: UPS, Kjellman specimen 241 (Chamberlain and Irvine 1994: 183). The provisional typification of Adey (1970a: 228) is not in accord with the ICBN Art. 7.11 and thus cannot be accepted. The designation by Chamberlain and Irvine (1994: 183) is, however, in accord with Art. 7.11 , even though reference is made to the provisional typification of Adey (1970a). Chamberlain and Irvine (1994: 183) explicitly stated though that they had not seen and thus examined the lectotype (Woelkerling et al. 2005).

Description: Plants non-geniculate, thallus-forming freeliving rhodoliths with fruticose growth form (Fig. 4a). Protuberances are generally terete and measure $4-10 \mathrm{~mm}$ in length and 2-4 $\mathrm{mm}$ in diameter. Thallus pseudoparenchymatous with dorsiventral internal organization in encrusting portions and radial internal organization in protuberances. Monomerous thallus construction in encrusting portions (Fig. 4b) consisting of a single system of branched filaments that form a core running more or less parallel to the substratum and a more peripheral region in which portions of core filaments or their derivatives curve outwards toward the thallus surface. The developing filamentous core is plumose (non-coaxial) with cells of adjacent filaments not arranged in arching tiers. Cells of adjacent filaments linked by lateral cell fusions (Fig. 4b), generally presenting small bodies near the primary pit connections as described in Adey (1970a) (Fig. 4c). Peripheral filaments terminating in a single layer 


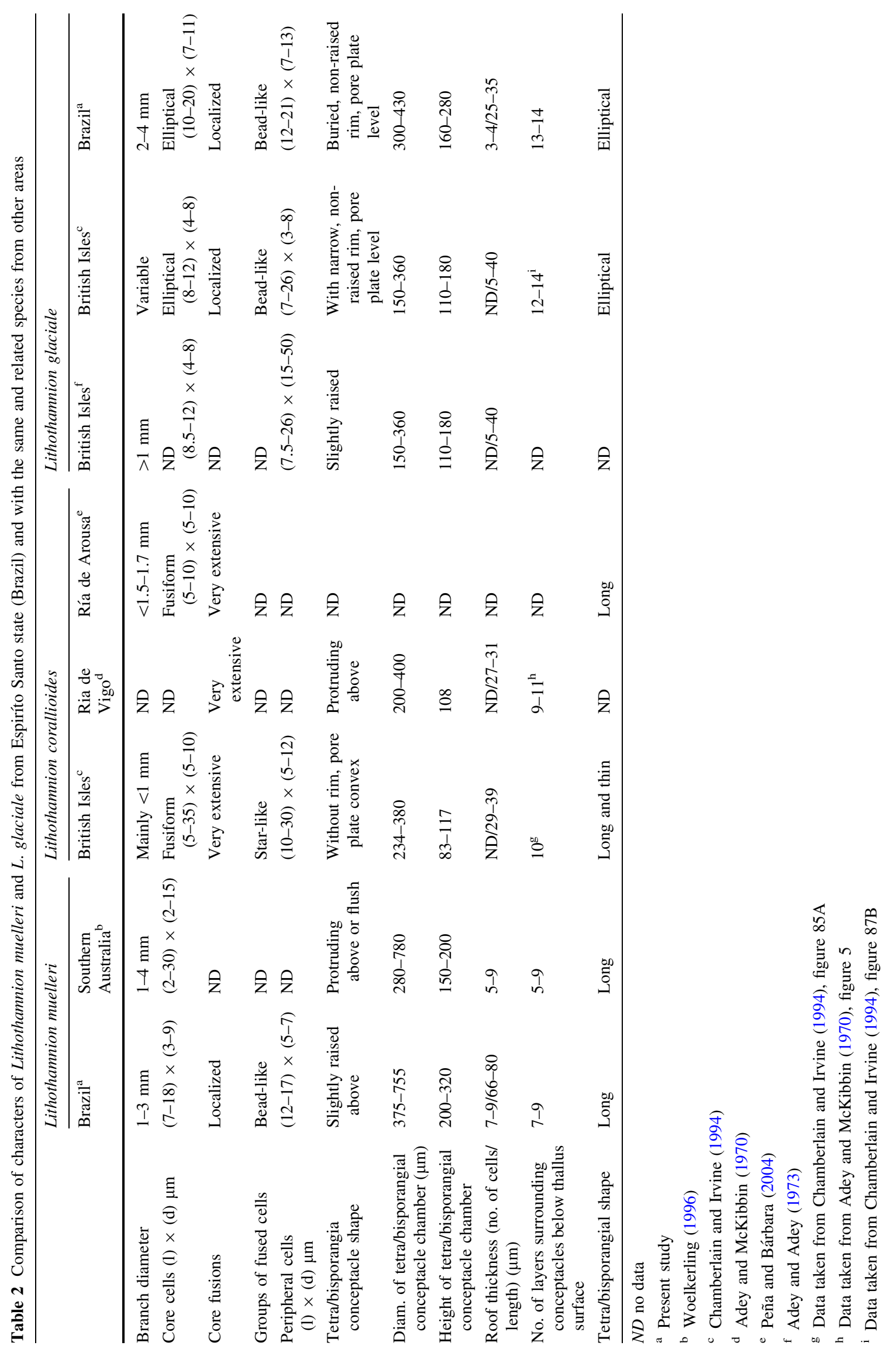


of flared epithallial cells (Fig. 4c) that measure 4-7 $\mu \mathrm{m}$ in length and 9-12 $\mu \mathrm{m}$ in diameter. Subepithallial cells rounded measuring $21-22 \mu \mathrm{m}$ in length and $10-12 \mu \mathrm{m}$ in diameter. Core cells are elliptical in shape measuring $10-20 \mu \mathrm{m}$ in length and 7-11 $\mu \mathrm{m}$ in diameter. Bead-like cell fusions between core filaments are restricted to certain random areas of the thallus. Cells of the peripheral filaments are generally rectangular measuring 12-21 $\mu \mathrm{m}$ in length and 7-13 $\mu \mathrm{m}$ in diameter. Trichocytes have not been observed.

Bisporangial conceptacles multiporate buried within the thallus with non-raised rim and pore plate level (Fig. 5a) with conceptacle roofs 3-4 cells including the epithallial cell (Fig. 5b). Conceptacle chambers 300-430 $\mu \mathrm{m}$ in diameter and 160-280 $\mu \mathrm{m}$ in height with the chamber floor located 13-14 cell layers below the surrounding thallus surface. Bispores elliptical measuring 30-32 $\mu \mathrm{m}$ in diameter and 49-51 $\mu \mathrm{m}$ in height and (Fig. 5c).

Material examined: Ibiraçu, Espírito Santo, Brazil, $19^{\circ} 49^{\prime} 00^{\prime \prime} \mathrm{S}, 37^{\circ} 56^{\prime} 00^{\prime \prime}$ (54 m depth, 31.x.1997, RB 458706); Alegre, Espírito Santo, Brazil, $20^{\circ} 45^{\prime} 00^{\prime \prime} \mathrm{S}, 40^{\circ} 10^{\prime} 00^{\prime \prime} \mathrm{W}$ (55 m depth, 03.xi.1997, RB 458707).

Comments: Most characters (Table 2) observed in the examined specimens agree with descriptions of the same species from the British Isles (Adey and Adey 1973; Chamberlain and Irvine 1994) and the Arctic seas (Kjellman 1883). Lithothamnion glaciale has previously been recorded only from temperate waters of the North Atlantic Ocean. There are deep-water records down to $34 \mathrm{~m}$ depth (Chamberlain and Irvine 1994) and 40 m (Adey and Adey 1973) throughout the northern British Isles, south to northern Devon (Lundy) and Yorkshire, in Ireland, Arctic Russia to British Isles, Iceland, Faroes, western Baltic Arctic Canada to USA, Greenland, Japan and China (Chamberlain and Irvine 1994). Adey (1966, as Lithothamnium "a") showed that it formed $38.4 \%$ of total coralline cover from low tide level down to $17 \mathrm{~m}$ in the Gulf of Maine, and Adey et al. (1976) recorded this species as one of the principal deep-water crustose Corallines of Japan occurring over $60 \mathrm{~m}$. The species has also been found in Quebec, Canada by dredging in a non-specific depth (Cardinal et al. 1979) and in up to $15 \mathrm{~m}$ depth at the northeastern coast of the United States (Adey 1970a). It is also recorded from the Arctic Sea (Kjellman 1883) except in the Siberian and Kara Sea. The current study is the first reporting of the species for the southern Atlantic Ocean. Records from Hamel and Lemoine (1953) from France are unconfirmed (Chamberlain and Irvine 1994).

\section{Discussion}

Spongites yendoi has a variable external morphology; especially, the degree of wartiness and whether adjacent thallus margins are flush with or overgrown by each other may vary considerably. Herbivore grazing commonly affects the physiognomy of $S$. yendoi (Maneveldt and Keats 2008). The shape of tetra/bisporangial conceptacles is raised, flush with, or sunken below the thallus surface. The character that is regarded as being noticeably consistent is the peripheral structure, which comprises most of the thallus thickness and is composed mainly of small, squarish cells. The core region is considered to be relatively thin and composed of elongate cells (Chamberlain 1993). Variations, particularly in external morphology, are directly attributed to habitat influences (Maneveldt and Keats 2008). A wide range of variation in conceptacle size and degree of prominence is seen (Chamberlain 1993; Maneveldt and Keats 2008). Normally, S. yendoi produces a lumpy or protuberant crust, but plants may also become smooth when they are grazed. Populations of $S$. yendoi in the north of Richards Bay (South Africa), the northern limit of the geographic extent of $S$. cochlear along the East Coast, are sparse, patchy, thick and protuberant. Because grazing reduces the number of protuberances, there is in general less surface area for conceptacle production. Furthermore, grazing even alter the size, shape and internal dimensions of the conceptacles in this place (Maneveldt and Keats 2008). In Brazil, the external morphology is warty with individual thalli overgrowing each other. Tetra/ bisporangial conceptacles are generally conical with a larger chamber diameter than those generally reported from Australia (Penrose 1996) and South Africa (Penrose 1991; Chamberlain 1993), but similar conceptacle diameters are reported from Mexican and the Caribbean (Mateo-Cid et al. 2007).

Spongites yendoi is similar to both Spongites decipiens (Foslie) Chamberlain and Spongites tunicatus Penrose. The species differs from $S$. decipiens in having a monomerous thallus construction and not a strictly dimerous one. Moreover, cells of the basal filaments in S. decipiens are notably larger in diameter than cells of the core filaments in S. yendoi (Chamberlain 1993). The species differs from $S$. tunicatus in lacking a corona of filaments in the pore canals of tetra/bisporangial conceptacles (Penrose 1996).

The character that delimits Lithothamnion muelleri from other species of Lithothamnion is that the cells of filaments bordering the pore canals in tetra/bisporangia conceptacles do not differ in size and shape from other cells of the roof (Wilks and Woelkerling 1995). The Brazilian specimens of Lithothamnion reported here possess this same feature. Tetra/bisporangia conceptacle chamber heights in the Brazilian material are, however, slightly larger than those reported from Australia (Woelkerling 1996).

Lithothamnion glaciale is similar to three other species of Lithothamnion namely Lithothamnion tophiforme (Esper) Unger (Adey et al. 2005), Lithothamnion lemoineae Adey 
(Adey 1970a) and Lithothamnion corallioides (Crouan and Crouan) Crouan and Crouan (Chamberlain and Irvine 1994). L. glaciale differs from L. lemoineae by possessing tetra/ bisporangial conceptacles that are usually taller and from L. tophiforme by possessing fewer cells in the tetra/bisporangial conceptacle roof. The occurrence of large "staining bodies" (phosphotungstic hematoxylin) in some species of crustose corallines has been previously described (Adey 1966). Possibly these structures are storage proteins (Adey and Mckibbin 1970). L. glaciale has small bodies near the primary pit connections ("pit bodies"), and L. tophiforme has abundant, large "staining bodies". In L. lemoineae, large "pit bodies" have been reported in the upper perithallium especially in the tetra/bisporangial conceptacle roofs (Adey 1970a). In L. corallioides, these bodies if present are extremely small, although thin staining plates are usually seen at the end of cells (Adey and Mckibbin 1970). L. glaciale and L. corallioides differ in the protuberance diameter, which is greater in L. glaciale. Furthermore, the tetra/bisporangial conceptacle pore plate is flush with the surrounding thallus surface in L. glaciale and raised in L. corallioides, and the chamber diameter and height of the multiporate conceptacles are larger in L. glaciale. Moreover, the most reliable character in distinguishing L. glaciale from L. corallioides is the difference in thallus core structure. In L. glaciale, the core cells are elliptical in shape (bead-like), and cell fusions between core filaments are restricted to certain random areas of the thallus. In L. corallioides, core cells are fusiform (star-like) in shape, and their cell fusions are very extensive (Chamberlain and Irvine 1994). The Brazilian rhodoliths identified as L. glaciale possess large terete protuberances, bear conceptacles with flush pore plates and possess cell fusions within the core region of the thallus that are restricted to certain random areas of the thallus, all features consistent with that reported for L. glaciale elsewhere. L. glaciale differs from the previously described L. muelleri by (1) possessing a thinner roof and fewer cells in their tetra/bisporangial conceptacle roofs and (2) by the shape of the cells in the tetra/bisporangial conceptacle roof that differ in size and shape from other cells of the roof. In L. muelleri, the cells of filaments bordering the pore canals in tetra/bisporangia conceptacles do not differ in size and shape from other cells of the roof.

Lithothamnion glaciale is a polar to cold-temperate species (Adey and Adey 1973). As such, its growth rate is reported to be limited by temperatures above $15^{\circ} \mathrm{C}$ (Adey 1970b). At 50-64 m depth off the continental shelf at Espírito Santo State where it was encountered here for the first time, water temperatures are similarly low also enabling the existence of other temperate seaweeds such as the deep-water kelp Laminaria abyssalis Joly and Oliveira (Yoneshigue-Valentin et al. 1995), which may survive temperatures of $24^{\circ} \mathrm{C}$ but has its growth optimum at $15-20^{\circ} \mathrm{C}$ (Tom Dieck and de Oliveira 1993). At $50 \mathrm{~m}$ depth, this region is influenced by the South Atlantic Central Waters (SACW) characterized by temperatures of 6-20 ${ }^{\circ} \mathrm{C}$ (Silveira et al. 2000). This may explain survival of L. glaciale in Brazilian tropical deep waters.

Based on the published literature, until now, 28 species of non-geniculate coralline red algae from Brazilian waters have been reported (Taylor 1960; Figueiredo and Steneck 2002; Tâmega and Figueiredo 2005, 2007; Villas-Boas and Figueiredo 2005; Rocha et al. 2006; Nunes et al. 2008; Villas-Boas et al. 2009; Farias et al. 2010; Amado-Filho et al. 2010; Bahia et al. 2011). This study presents two new records for Brazil, increasing the number to 30 species. The genus Spongites was previously recorded for Brazil at 2-4 m depth along southeastern shores (Tâmega and Figueiredo 2005), but the species remained unidentified. Therefore, this is the first record of $S$. yendoi for Brazil. Lithothamnion occidentale (Foslie) Foslie and L. sejunctum Foslie were previously reported from shallow Brazilian coral reefs (Figueiredo and Steneck 2002) but without a full species description. The first species of Lithothamnion described from Brazilian waters was L. superpositum Foslie from Bahia, Rio Grande do Norte and Santa Catarina states (Farias et al. 2010) and L. muelleri from shallow waters in Espírito Santo state (Amado-Filho et al. 2010). This study is the first report and description of polar to cold-temperate L. glaciale from Brazilian waters and extends the depth range of non-geniculate coralline red algae down to $58 \mathrm{~m}$ in Brazilian waters.

Acknowledgments We are grateful to Rio de Janeiro Research Foundation (FAPERJ) for the studentship to the first author and for the travel and research grants for the last two authors; Fundação O Boticario de Proteção à Natureza for financial support; Yocie Yoneshigue Valentin provided coralline algae samples from REVIZEE. We acknowledge the support of SEP CONACYT and UABCS. We thank the considerable constructive criticism of two anonymous reviewers on an earlier draft of the manuscript and the orthographic corrections of Dr. Ivan Hole.

\section{References}

Adey WH (1966) The genus Pseudolithophyllum (Corallinaceae) in the Gulf of Maine. Hydrobiologia 27:479-497

Adey WH (1970a) The crustose corallines of the northwestern North Atlantic, including Lithothamnion lemoineae n. sp. J Phycol 6:225-229

Adey WH (1970b) The effects of light and temperature on growth rates in boreal-subarctic crustose corallines. J Phycol 6:269-276

Adey WH, Adey PJ (1973) Studies on the biosystematics and ecology of the epilithic crustose corallinaceae of the British Isles. Eur J Phycol 8:343-407

Adey WH, Mckibbin DL (1970) Studies on the maerl species Phymatolithon calcareum (Pallas) nov. comb. and Lithothamnium coralloides Crouan in the Ria de Vigo. Bot Mar 13:100-106

Adey WH, Masaki T, Akioka H (1976) The distribution of crustose corallines in Eastern Hokkaido and the biogeographic 
relationships of the flora. Bulletin of the Faculty of Fisheries, vol 26. Hokkaido University, pp 303-313

Adey WH, Chamberlain YM, Irvine LM (2005) An SEM-based analysis of the morphology, anatomy and reproduction of Lithothamnion tophiforme (Esper) Unger (Corallinales, Rodophyta), with a comparative study of associated North Atlantic Arctic/Subarctic Melobesioideae. J Phycol 41:1010-1024

Amado-Filho G, Maneveldt G, Manso RCC, Marins-Rosa BV, Pacheco MR, Guimarães SMPB (2007) Structure of rhodolith beds from 4 to 55 meters deep along the southern coast of Espírito Santo State, Brazil. Cienc Mar 33:399-410

Amado-Filho GM, Maneveldt GW, Pereira-Filho GH, Manso RCC, Bahia RG, Barros-Barreto MB, Guimarães SMPB (2010) Seaweed diversity associated with a Brazilian tropical rhodolith bed. Cienc Mar 36:371-391

Bahia RG, Riosmena-Rodriguez R, Maneveldt GW, Amado-Filho GM (2011) First reporto f Sporolithon ptychoides (Sporolithales, Corallinophycidae, Rhodophyta) for the Atlantic Ocean. Phycol Res 59:64-69

Cardinal A, Cabioch J, Gendron L (1979) Les Corallinacées (Rhodophytes-Cryptonemiales) des côtes du Québec. Cah Biol Mar 10:171-179

Chamberlain YM (1993) Observations on the crustose coralline red alga Spongites yendoi (Foslie) comb. nov. in South Africa and its relationship to $S$. decipiens (Foslie) comb. nov. and Lithophyllum natalense Foslie. Phycologia 32:100-115

Chamberlain YM, Irvine LM (1994) Melobesioideae Bizzozero. In: Irvine LM, Chamberlain YM (eds) Seaweeds of the British Isles, vol 1. Rhodophyta part 2B Corallinales, Hildenbrandiales. HMSO, London, pp 159-234

Farias JN, Riosmena-Rodriguez R, Bouzon Z, Oliviera EC, Horta PA (2010) Lithothamnion superpositum (Corallinales; Rhodophyta): first description for the Western Atlantic or rediscovery of a species? Phycol Res 58:210-216

Farr T, Broom J, Hart D, Neill K, Nelson W (2009) Common coralline algae of northern New Zealand: an identification guide. NIWA Information Series No. 70, Wellington, New Zealand, p 125

Figueiredo MAO, Steneck RS (2002) Floristic and ecological studies of crustose coralline algae on Brazil's Abrolhos reefs. In: Proceedings of 9th international coral reef symposium, vol 1, pp 493-498

Foslie M (1904) I. Lithothamnioneae, Melobesieae, Mastophoreae. In: Weber van Bosse A, Foslie M (eds) The Corallinaceae of the Siboga expedition. Siboga Exped, vol 61, pp 1-110

Foster MS (2001) Rhodoliths: between rocks and soft places. J Phycol 37:659-667

Fragoso D, Rodríguez D (2002) Algas coralinas no geniculadas (Corallinales, Rodophyta) en el Pacífico tropical mexicano. Anales del Instituto de Biologia, Universidad Autônoma de México, Série Botanica, vol 73, pp 97-136

Guimarães SMPB (2003) Uma análise da diversidade da flora marinha bentônica do estado do Espírito Santo, Brasil. Hoehnea 30:11-19

Hamel O, Lemoine MMEP (1953) Corallinaces de France et d'Afrique du Nord. Arch MNHN 1:15-136

Harvey AS, Woelkerling WJ (2007) A guide to nongeniculate coralline red algal (Corallinales, Rhodophyta) rhodolith identification. Cienc Mar 33:411-426

Harvey A, Woelkerling W, Farr T, Neill K, Nelson W (2005) Coralline algae of central New Zealand: an identification guide to common 'crustose' species. NIWA information series no. 57. Wellington, New Zealand, p 145

Holmgren PK, Holmgren NH (2011) continuously updated electronic resource. Index herbariorum: a global directory of public herbaria and associated staff. New York Botanical Garden's Virtual Herbarium. http://www.sweetgum.nybg.org/ih/

Joubin L (1913) Mélobésiées. Revision des mélobésiées Antarctiques par Mme Paul Lemoine. In: Stated EN (ed) Deuxième Expédition Antarctique Française (1908-1910) commandée par le Dr Jean Charcot. Sciences Naturelles, vol 1. Paris, Botanique, Masson et Cie, pp 1-67, pls 1-2. Note: Author listed as Mme P. Lemoine in the publication

Kempf M (1980) Perspectiva de exploração econômica dos fundos de algas calcárias da plataforma continental do nordeste do Brasil. Trabalhos do Instituto Oceanográfico da Universidade Federal de Pernambuco, vol 15, pp 139-164

Kempf M, Coutinho PN, Morais JO (1969) Plataforma continental do norte e nordeste do Brasil. Trabalhos do Instituto Oceanográfico da Universidade Federal de Pernambuco, vol 9, issue no 11, pp 9-15

Kjellman FR (1883) The algae of the Arctic Sea: a survey of the species, together with an exposition of the general characters and the development of the flora. K Sven Vetensk Akad Handl 20(5): $1-350$

Lavrado HP (2006) Caracterização do ambiente e da comunidade bentônica. In: Lavrado HP, Ignácio BL (eds) Biodiversidade bentônica da região central da Zona Econômica Exclusiva brasileira. Capítulo1. Rio de Janeiro, Museu Nacional, pp 19-64

Littler MM, Littler DS, Stephen MB, James NN (1985) Deepest known plant life discovered on an uncharted seamount. Science 227(4682):57-59

Lund MJ, Davies P, Braga JC (2000) Coralline algal nodules off Fraser Island, Eastern Australia. Facies 42:25-34

Maneveldt GW, Keats DW (2008) Effects of herbivore grazing on the physiognomy of the coralline alga Spongites yendoi and on associated competitive interactions. Afr $\mathrm{J}$ Marine Sci 30:581-593

Maneveldt GW, Chamberlain YM, Keats DW (2008) A catalogue with keys to the non-geniculate coralline algae (Corallinales, Rhodophyta) of South Africa. S Afr J Bot 74:555-566

Mateo-Cid LE, Mendoza-Gonzáles AC, Pedroche FF (2007) Spongites yendoi (Foslie) Y. Chamberlain (Corallinales, Rhodophyta) em La costa de México y Caribe Mexicano. Polibotánica 24:75-82

Moura CWN, Kraus JE, Cordeiro-Marino M (1997) Metodologia para obtenção de cortes histológicos com historesina e coloração com azul de toluidina $\mathrm{O}$ para algas coralináceas (Rhodophyta, Corallinales). Hoehnea 24(2):17-27

Nunes JMC, Guimarães SMPB, Donnangelo A, Faria J, Horta PA (2008) Aspectos taxonômicos de três espécies de coralináceas não articuladas do litoral do estado da Bahia, Brasil. Rodriguésia 59:75-86

Peña V, Bárbara I (2004) Diferenciación morfológica y anatómica entre Lithothamnion corallioides y Phymatolithon calcareum (Corallinales, Rhodophyta) en dos bancos de maërl de la Ria de Arousa (N. O. Península Ibérica). An Biol 26:21-27

Penrose D (1991) Spongites fruticulosus (Corallinaceae, Rhodophyta), the type of Spongites, in southern Australia. Phycologia 30:438-448

Penrose D (1996) Subfamily Mastophoroideae. In: Womersley HBSW (ed) The marine benthic flora of Southern Australia. Part IIIB, Gracilariales, Rhodymeniales, Corallinales and Bonnemaisoniales. Australian Biological Resources Study, Canberra, pp 237-283

Ramírez ME, Santelices B (1991) Catálogo de las algas marinas bentónicas de la costa temperada del Pacífico de Sudamérica. Monogr Biol 5:1-437

Rocha MR, Metri R, Omuro JY (2006) Spatial distribution and abundance of ascidians in a bank of coralline algae at Porto 
Norte, Arvoredo Island, Santa Catarina. J Coastal Res 40:1676-1679

Silveira ICA, Schmidt ACK, Campos EJD, Godoi SS, Ikeda Y (2000) A corrente do Brasil ao largo da costa leste brasileira. Ver Bras Oceanogr 48:171-183

Tâmega FTS, Figueiredo MAO (2005) Distribuição das algas calcárias incrustantes (Corallinales, Rhodophyta) em diferentes habitats na Praia do Forno, Armação dos Búzios, Rio de Janeiro. Rodriguésia 56(87):123-132

Tâmega FTS, Figueiredo MAO (2007) Distribution of crustose coralline algae (Corallinales, Rodopyta) in the Abrolhos Reefs, Bahia, Brazil. Rodriguésia 58:941-947

Taylor WR (1960) Marine algae of the eastern tropical and subtropical coast of the Americas. University of Michigan press, EUA, p 870

Tom Dieck I, de Oliveira EC (1993) The section Digitatae of the genus Laminaria (Phaeophyta) in the northern and southern Atlantic: crossing experiments and temperature responses. Mar Biol Berl 115:151-160

Villas-Boas AB, Figueiredo MA (2005) Colonization and growth of coralline algae (Corallinales, Rhodophyta) on the Rocas Atoll. Braz J Oceanogr 53:147-156

Villas-Boas AB, Riosmena-Rodriguez R, Amado-Filho GM, Maneveldt GW, Figueiredo MAO (2009) Rhodolith-forming species of Lithophyllum (Corallinales; Rhodophyta) from Espírito Santo State, Brazil, including the description of L. depressum sp. nov. Phycologia 48(4):237-248

Wilks KM, Woelkerling WJ (1995) An account of southern Australian species of Lithothamnion (Corallinaceae, Rhodophyta). Aust Syst Bot 8:549-583

Woelkerling WJ (1983) A taxonomic reassessment of Lithotharnniurn Philippi (Corallinaceae, Rhodophyta) based on studies of R.A. Philippi's original collections. Br Phycol J 18:165-197
Woelkerling WJ (1988) The coralline red algae: an analysis of the genera and sub-families of nongeniculate Corallinaceae. British Museum of Natural History and Oxford University Press, London, p 268

Woelkerling WJ (1993) Type collections of Corallinales (Rhodophyta) in the Foslie Herbarium (TRH). Gunneria 67:1-289

Woelkerling WJ (1996) Subfamily Melobesioideae. In: Womersley HBSW (ed) The marine benthic flora of Southern Australia. Part IIIB, Gracilariales, Rhodymeniales, Corallinales and Bonnemaisoniales. Australian Biological Resources Study, Canberra, pp 164-210

Woelkerling WJ, Irvine LM, Harvey AS (1993) Growth-forms in nongeniculate coralline red algae (Corallinales, Rhodophyta). Aust Syst Bot 6:277-293

Woelkerling WJ, Gustavsen G, Myklebost HE, Prestø T, Såstad SM (2005) The coralline red algal herbarium of Mikael Foslie: revised catalogue with analyses. Trondheim: Museum of Natural History and Archaeology, Norwegian University of Science and Technology. Notes: Vol 77 in the irregularly published series Gunneria, pp 1-625

Yabur-Pacheco R, Riosmena-Rodriguez R (2006) Rhodolith bed composition in the southwestern Gulf of Califórnia, México. The Nagisa World Congress, pp 37-47

Yoneshigue-Valentin Y, Mitchell GJP, Gurgel CFD (1995) Quelques observations préliminaires sur les macroalgues de la plate-forme continentale du sud-est brésilien. Acta Bot Gallica 142:161-165

Yoneshigue-Valentin Y, Gestinari LMS, Fernández DRP (2006) Macroalgas. In: Lavrado HP, Ignacio BL (eds) Biodiversidade bentônica da região central da Zona Econômica Exclusiva brasileira. Capítulo2. Rio de Janeiro, Museu Nacional, pp 67-105 